\title{
Phytopathogenic fungi with potential as biocontrol agents for weeds of importance in crops of Antioquia, Colombia
}

Yerly Mira ${ }^{1 *} \mathbb{B}$, Darío Castañeda ${ }^{1}$, Juan Morales ${ }^{1}$ and Luis Patiño ${ }^{2}$

\begin{abstract}
Background: Use of phytopathogenic fungi for the biocontrol of weeds represents a promising path in the search for new management alternatives that allow reducing negative effects on the environment and the generation of biotypes having resistance to herbicides. The first step in developing weed biological control programs is to determine the plants and their natural enemies with the highest affinity and potential to achieve effective biocontrol. The objective of the present study was to evaluate the phytopathogenic potential of fungal isolates on four economically important weeds including: Rumex crispus L., Digitaria horizontalis Willd, Persicaria nepalensis (Meisn.) Miyabe, and Thunbergia alata Bojer ex Sims, as a possible biocontrol agent.

Results: Morphological and molecular identification of nine phytopathogenic isolates of weeds was achieved, according to the sequencing of the ITS, $\beta$-Tub2, and TEF1-a regions. Pathogenicity of the following species on original hosts was confirmed: Colletotrichum cigarro, Epicoccum draconis, and Didymella rumicicola on R. crispus; Bipolaris sp., on D. horizontalis; Bipolaris zeicola, Phialemoniopsis curvata, and Stemphylium beticola on P. nepalensis and, Alternaria thunbergiae and Nigrospora sphaerica on T. alata. These could be, fairly, considered the first worldwide reports of such interactions, except for $A$. thunbergiae and Bipolaris sp. The most virulent interactions according to the AUDPC value corresponded to $(R$. crispus $\times$ D. rumicicola), $(D$. horizontalis $\times$ Bipolaris sp.), $(P$. nepalensis $\times S$. beticola) and (T. alata $\times A$. thunbergiae), with an incidence of $100 \%$.
\end{abstract}

Conclusion: These strains were proposed for future research as potential biocontrol agents, which represented a great resource for the possible generation of new bio-herbicides.

Keywords: Biological control, Weeds, Crop protection, Weed diseases, Phytopathogenic fungi, Molecular identification

\section{Background}

Agricultural pests are estimated to cause annual total losses of US\$ 248 billion in global agriculture (Fried et al. 2017). It is considered that the interference caused by weed plants represents the highest value of these losses, even above the damage caused by arthropods

\footnotetext{
*Correspondence: ydmirat@unal.edu.co

${ }^{1}$ Departamento de Ciencias Agronómicas, Facultad de Ciencias Agrarias, Universidad Nacional de Colombia, Sede Medellín, Cra 65 No 59A-110, Núcleo El Volador, B11, Medellín, Antioquia, Colombia

Full list of author information is available at the end of the article
}

and pathogens (Zohaib et al. 2016). Weed management by application of herbicides of chemical synthesis has been perceived by farmers as a short-term, easy, fast, and profitable solution (Triolet et al. 2019). However, possible adverse effects of herbicides on human health and the environment, combined with the increase of plant species having resistance to such products and the lack of new molecules, have led to the need of exploring new alternatives for efficient and sustainable weed management. Currently, there are about 496 biotypes of plants having herbicide resistance, distributed in 23 of the 26 known sites of action (Heap 2014). 
Biological control as an integral part of the sustainable management of weeds represents an emerging and promising method for reducing the problem. Historically, phytopathogenic fungi and specific insect feeders, for the biocontrol of weeds, have been the most outstanding and researched alternative (Cai and Gu 2016). Several successful studies indicating the biological values of phytopathogenic fungi around the world demonstrated the feasibility of its application in agriculture (Schwarzländer et al. 2018), which has been evidenced by the generation of 17 commercial mycoherbicides registered to date (Kumar et al. 2018b). The most important characteristics of these agents include high virulence on target plants, the establishment of high populations in host plants, ease of producing and storing of a suitable formulation, and safety on non-target species (Auld et al. 2003). For the implementation of a biocontrol strategy, it is first necessary to choose appropriate weed species for evaluation using basic selection criteria, such as the difficulty of their control using conventional methods, development of resistance to chemical herbicides, prohibition of their use, and/or prohibitive costs (Castaño 2012). Secondly, to implement phytopathological studies that allow the identification of such fungal isolates capable of affecting and/ or regulating weed growth (Bailey 2014).

Zaller (2004) pointed to Rumex crispus L. (Polygonaceae) as one of the most important undesirable perennials in agriculture in the world, capable of competing strongly with herbaceous crops, especially pastures. Digitaria horizontalis Willd (Poaceae) stands out as a grass-high invasion potential, being problematic in at least 60 countries and more than 30 crops of economic importance (Dias et al. 2005). Persicaria nepalensis (Meisn.) Miyabe (Polygonaceae) is an invasive species in several tropical countries of the world, especially harmful to annual crops between 1200 and $2500 \mathrm{~m}$ above sea level, such as potatoes and vegetables (Quijano et al. 2019). In Colombia, Thunbergia alata Bojer ex Sims (Acanthaceae) is classified as a threat to native ecosystems rapidly invading forests, protected areas, wetlands, roadsides, and open fields (Cárdenas et al. 2017). In crops grown in a moderately cold climate in Antioquia, Colombia, the previously mentioned weeds were recognized as important weed species with priority for their control, due to their highly competitive ability, dominance, and distribution in the crops (Ramírez 2017). Mira (2020) identified weed species from Antioquia, Colombia, as potential candidates for biological control studies using phytopathogenic fungi; among which, these four weeds, represented the highest values. Bioprospecting studies are necessary to contribute to the discovery of potential fungal strains for future biological control programs of weed in Colombia. The objective of this research was to identify and evaluate phytopathogenic fungi of $R$. crispus, $D$. horizontalis, $P$. nepalensis, and T. alata, as potential biocontrol agents.

\section{Methods \\ Area of study}

$R$. crispus, D. horizontalis, P. nepalensis, and T. alata were previously recognized as target species for biological control studies, according to the importance index and phytosanitary status of weeds (IEFS) and the agronomic damage parameter (PA) (Mira 2020). Sampling was carried out during 2018, in four agricultural farms located at the municipalities of San Vicente $\left(6^{\circ} 16^{\prime} 55^{\prime \prime} \mathrm{N}\right.$ $75^{\circ} 19^{\prime} 56^{\prime \prime} \mathrm{O}$, altitude 2236 m.a.s.l.), Marinilla $\left(6^{\circ} 7^{\prime} 48^{\prime \prime} \mathrm{N}\right.$ $75^{\circ} 23^{\prime} 24^{\prime \prime} \mathrm{O}$, altitude 2120 m.a.s.l.), El Retiro $\left(6^{\circ} 03^{\prime} 35^{\prime \prime} \mathrm{N}\right.$ $75^{\circ} 30^{\prime} 14^{\prime \prime} \mathrm{W}$, altitude 2195 m.a.s.l.) and El Carmen de Viboral $\left(06^{\circ} 05^{\prime} 06^{\prime \prime} \mathrm{N} 75^{\circ} 20^{\prime} 19^{\prime \prime} \mathrm{W}\right.$, altitude 2182 m.a.s.l.) in Antioquia, Colombia. According to Holdridge (1982), the life zones correspond to Low Montane Humid Forest and Low Montane Highly Humid Forest. At the time of sampling, farms were mainly dedicated to production of beans, avocado, corn, and tomato, respectively. Visits were conducted to search for each of the four species with the presence of symptoms of fungal diseases in the early stages of development. Symptoms were described and captured through images. Symptomatic leaf tissues were collected and packed properly until laboratory processing. Additionally, from adult and healthy plants, seeds of each weed species were obtained for subsequent propagation and realization of pathogenicity tests.

\section{Fungal isolates}

Phytopathological procedures were carried out in the laboratory and greenhouse of the National University of Colombia, branch Medellín. $\left(6^{\circ} 15^{\prime} 47^{\prime \prime} \mathrm{N}\right.$ and $75^{\circ} 34^{\prime} 40^{\prime \prime} \mathrm{W}$, altitude 1475 m.a.s.l). Samples were superficially washed with water and dried in the open air on sterile paper. From each type of lesion, four fragments of $(5 \times 5 \mathrm{~mm}$ each) were cut and superficially disinfected with $70 \%$ ethanol (1 $\mathrm{min})$, rinsed in sterile distilled water, followed by $1 \%$ sodium hypochlorite $(2 \mathrm{~min})$, and sterile water (2 min). Plant tissue fragments were seeded in commercial potato dextrose agar (PDA) culture medium, supplemented with ampicillin $(1 \mu \mathrm{l} / \mathrm{ml})$, and incubated at room temperature $\left( \pm 24{ }^{\circ} \mathrm{C}\right)$, with $8 / 16 \mathrm{~h}(\mathrm{D} / \mathrm{L})$. Isolates were replicated until pure colonies were obtained.

\section{Morphological identification of phytopathogens}

For microscopic descriptions, cultures grown in PDA medium, incubated at room temperature $\left( \pm 24{ }^{\circ} \mathrm{C}\right)$, and in a regime of $8 / 16 \mathrm{~h}(\mathrm{D} / \mathrm{L})$ for four to five weeks. Aspects such as type of mycelium, type, shape, diameter, and color of reproductive structures were described. Fungal 
structures were observed under a Nikon Eclipse E200 LED optical microscope coupled to a digital camera system. For characterization of colonies, a $(4 \mathrm{~mm}$ diameter mycelial disc) was placed in the center of a Petri-dish with PDA medium and kept at $\left( \pm 24^{\circ} \mathrm{C}\right)$. After $7-15$ days of incubation, aspects such as texture, shape, margin, sectorization, elevation of mycelium, presence or absence of exudates, pigmentation, and color were described, both for the upper and lower faces of the Petri-dish. The information obtained was compared by fungal taxonomic keys described by Barnett and Hunter (2006) and with the search tools available on Mycobank site for identification (http://www.mycobank.org/).

\section{Molecular identification of phytopathogens}

Fungi were identified by sequencing the Internal Transcribed Spacer (ITS) region of ribosomal RNA, with primers ITS1 (5'-TCCGTAGGTGAACCTGCGG-3') and ITS4 ( $5^{\prime}$-TCCTCCGCTTATTGATATGC-3') (White et al. 1990), the Beta-Tubulin region ( $\beta$-Tub2) with primers CYLTUB1F (5'-AAATTGGTGCTGCTTTCTGG-3') and CYLTUB1R ( $5^{\prime}$-AGTTGTCGGGACGGAAGAG-3') (Groenewald et al. 2013), and the region of transcription elongation Factor E1 $\alpha$ (TEF1 $\alpha$ ), with primers EF1-728F (5'-CATCGAGAAGTTCGAGAAGG-3') and EF1-986R (5'TACTTGAAGGAACCCTTACC-3') (Carbone and Kohn 1999).

\section{DNA extraction}

Pure isolates of the fungi were placed in flasks with liquid potato-dextrose (PD) culture medium and incubated at room temperature in dark for 10 days. DNA of each isolate was extracted, using the CTAB 3X method (Doyle and Doyle 1990). The quality and integrity of DNA were verified, using $1.5 \%$ agarose gel electrophoresis (SIGMA), in 0.5X TBE buffer, stained with GelRed $(1 \mu \mathrm{l})$, and visualized in a trans-illuminator with UV light (BioDoc-IT Imagen System, UVP). DNA concentration was quantified by spectrophotometry on a NanoDrop 2000C (Thermo, USA).

\section{PCR amplification and sequencing}

For each PCR reaction, the following reagents were gently mixed at the indicated final concentrations: $1 \times$ Buffer PCR, $0.25 \mathrm{mM}$ dNTPs, $1.5 \mathrm{mM} \mathrm{MgCl} 2,0.2 \mu \mathrm{M}$ of each primer, $5 \mathrm{U}$ of Taq polymerase (Thermo Scientific), $25 \mathrm{ng} / \mu \mathrm{L}$ of DNA, and molecular biology grade water to make a final volume of $25 \mu \mathrm{L}$. The amplification program consisted of an initial denaturation at $95{ }^{\circ} \mathrm{C}$ for $3 \mathrm{~min}$, followed by 35 cycles as follows: denaturation at $95{ }^{\circ} \mathrm{C}$ for $30 \mathrm{~s}$, annealing at $55^{\circ} \mathrm{C}$ for ITS primers, $59.6^{\circ} \mathrm{C}$ for $\beta$-Tub2 primers and, $56.9{ }^{\circ} \mathrm{C}$ for TEF1 $\alpha$ primers for
$1 \mathrm{~min}$, extension at $72{ }^{\circ} \mathrm{C}$ for $1 \mathrm{~min}$ and at the end of the 35 cycles a final extension at $72{ }^{\circ} \mathrm{C}$ for $10 \mathrm{~min}$ was performed. The process was carried out in a $\mathrm{T} 100^{\mathrm{TM}}-\mathrm{Bio}-$ Rad Thermal Cycler. PCR products were visualized in $1.5 \%$ agarose gel electrophoresis, as described previously, and the size of fragments was verified by comparison to the Generuler Plus 100 bp molecular weight marker (Thermo Scientific). Amplicons were purified, using the commercial QIAquick PCR Purification (Qiagen, USA) and sent to the sequencing service at Macrogen Inc., (Republic of Korea).

\section{Phylogenetic analysis}

Sequences obtained with each primer were edited and assembled, using BioEdit 7.2 software (Hall 1999). Consensus sequences were compared to databases available in GenBank, using the BLAST program (http://www. ncbi.nlm.nih.gov/BLAST). With the results obtained, a matrix was built from cured and representative sequences of each isolate. Multiple sequence alignment was performed using the Clustal W algorithm. Sequences of good quality were concatenated, and phylogenetic trees were constructed using the Maximum Likelihood (ML) method implemented in MEGA X software (Kumar et al. 2018a). Each analysis was performed with 1000 Bootstrap replicas using the model suggested by the Bayesian information criterion and as external groups, sequences from other closely related fungal genera were used.

\section{Pathogenicity tests on detached leaves}

Pathogen inoculum was obtained from strains cultivated for 15 days in PDA medium, under 12/12 h (D/L), and at $24{ }^{\circ} \mathrm{C}$. Leaves of each weed species were superficially disinfected with $1 \%$ hypochlorite $(3 \mathrm{~min})$ and rinsed with sterile water $(5 \mathrm{~min})$. For each isolate obtained, two inoculation methods were evaluated: (1) agar discs with mycelium and (2) spore and/or mycelial fragments suspensions. In the first method, two mycelial agar discs, $4 \mathrm{~mm}$ in diameter, were obtained directly from the growing edge of the colony and placed on each side of the midrib on the underside of leaves of each original host weed species. For the second method, spores or mycelial fragments were collected by flooding the cultural medium with sterile distilled water and scraping the mycelial growth area. The concentration of the suspension was quantified in a Neubauer chamber and adjusted to $1 \times 10^{6}$ spores-mycelium fragments $/ \mathrm{ml}$. Two aliquots of $6 \mu \mathrm{L}$ each of the suspension from each isolate, were deposited on each side of the midrib of the underside of leaves obtained from the original host. As a control, sterile agar discs and aliquots of sterile water were inoculated 
on each side of the midrib on the undersides of leaflets of each evaluated weed. Inoculated leaves were placed in humid chambers, which consisted of plastic trays with a sterile distilled water film at the bottom, which was kept hermetically covered at room temperature $\left( \pm 24^{\circ} \mathrm{C}\right)$. As response variables, the incubation period, disease incidence, and lesion length and width were measured daily up to a maximum of 10 days. Daily development of lesion size was used to estimate the area under disease progress curve (AUDPC), assuming an ellipsoidal shape (Campbell and Madden 1990). Pathogenicity of each isolate on its respective host was represented by the evaluation of the two inoculation methods and their two respective controls. Four replicates of each treatment were carried out, using each leaf as an experimental unit. The whole experiment was repeated three times independently, following the same procedure.

\section{Pathogenicity tests on seedlings}

From seeds sown in pots with a capacity of $2 \mathrm{~kg}$ of soil, seedlings of 4 to 6 true leaves/each were obtained from each of the four studied weed species under greenhouse conditions described. The fungal isolate that showed the greatest aggressiveness in the detached leaf test of each weed plant species was selected to be inoculated on complete seedlings of their respective original host. As inoculum source, $40 \mathrm{ml}$ of a suspension of each isolate at a concentration of $1 \times 10^{6}$ spores-mycelium fragments $/ \mathrm{ml}$ were used. Inoculum suspension was applied with a sterile brush on the undersides of all leaves of corresponding host seedlings and subsequently sprayed, using a manual atomizer, until completely covering the entire aerial part of the whole plant of each weed analyzed. As a control, seedlings sprayed with sterile distilled water were used, following the same procedure described. Treated plants were placed in a bioclimatic cabin, with $12 / 12 \mathrm{~h}(\mathrm{~L} / \mathrm{D})$, at $21{ }^{\circ} \mathrm{C}$ and relative humidity more than $80 \%$, for a maximum of 8 days. The incubation period, disease incidence, and severity were recorded. The area of the lesion was estimated, using the ImageJ 1.x program, as the proportion of affected leaf area concerning the total leaf area, expressed as a percentage; for which, all the leaves of each plant were detached, and photographs were captured at the same height (Schneider et al. 2012). Infected leaflets were taken 8 days after inoculation (dai) for $R$. crispus, 5 dai for $D$. horizontalis and P. nepalensis, and 3 dai for T. alata.

The pathogenicity of each of the four isolates on their respective host seedlings was tested using the described inoculation method and their respective controls. Each treatment had six replications taking each plant as an experimental unit, the experiment was repeated twice in time.

\section{Koch postulates}

In both pathogenicity tests, re-isolations were made from diseased tissues to verify compliance with Koch's postulates. A symptomatic leaf of each treatment was taken and cultivated in PDA medium, following the same protocol described and strains obtained were compared morphologically with the inoculated strains.

\section{Statistical analysis}

Homoscedasticity and normality of data were, respectively, verified according to Levine and Shapiro-Wilk test (2020). Since data did not meet assumptions of normality, non-parametric statistics were performed using the Kruskal-Wallis test (2020) and the Wilcoxon rank test (2020), using a 95\% confidence level. Analyzes were carried out using the statistical programming language and environment R-Project ${ }^{\circledR}$ version 3.6.1 (The R Core Time 2019).

\section{Results}

Fungal isolates

Nine pathogenic isolates were obtained and labeled according to their respective host weed as follows: R14, R15, and R19 from R. crispus; D30 from D. horizontalis; P4, P5, and P7 from P. nepalensis and T7 and T10 from T. alata. Typical symptoms observed in plants under natural infestation conditions are presented in Table 1.

\section{Molecular and morphological identification}

Isolate R14 - Colletotrichum cigarro (B.S. Weir \& P.R. Johnst.) A. Cabral \& P. Talhinhas. Synonymous: Colletotrichum kahawae subsp. cigarro (Cabral et al. 2020).

Hyaline conidia, without septa, unicellular, cylindrical in shape and smooth-walled, with dimensions between 9.1-14.1 $\mu \mathrm{m}$ long $\times 3.4-4.9 \mu \mathrm{m}$ wide; branched and septate hyphae. Colonies growing circular, with a smooth wavy margin, flat relief, and granular texture in the center, but cottony at the edges. Orange watery exudations were present after 15 days of culturing (Additional file 1: Fig. 1). Molecular identification was made, using concatenated sequences of the ITS and $\beta$ Tub2 regions. Analysis with BLASTn algorithm for ITS sequences showed homology to C. gloeosporioides and C. kahawae subsp. cigarro, with identities of (100\%) and 99.8\%, respectively, and for BTub2 to Colletotrichum kahawae subsp. cigarro, with (100\%) identity. The isolate named R14_ANT was associated with the clade of the species $C$. kahawae subsp. cigarro $(=$ C. cigarro $)($ bootstrap $=85 \%)$ (Additional file 1: Fig. 2).

Isolate R15 - Epicoccum draconis (Berk. ex Cooke) Qian Chen and L. Cai. Synonymous: Phoma draconis (Berk. Ex. Cooke) Boerema (Chen et al. 2015). 
Table 1 Symptomatology observed in the weeds: Rumex crispus, Digitaria horizontalis, Persicaria nepalensis, and Thunbergia alata under field conditions

\begin{tabular}{|c|c|c|c|}
\hline \multirow[t]{2}{*}{ Host weed } & \multicolumn{2}{|l|}{ Symptom } & \multirow{2}{*}{$\begin{array}{l}\text { Isolate } \\
\text { code }\end{array}$} \\
\hline & Description & Appearance & \\
\hline \multirow[t]{3}{*}{ R. crispus } & $\begin{array}{l}\text { Slightly round lesions dark brown necrotic in the center concentric in } \\
\text { appearance rough in texture and often with surrounding chlorotic areas }\end{array}$ & & R14 \\
\hline & $\begin{array}{l}\text { Small circular spots reddish or purple randomly distributed throughout the } \\
\text { leaf tissue and plant stem smooth in texture and often with a small whitish } \\
\text { center }\end{array}$ & & R15 \\
\hline & & & R19 \\
\hline D. horizontalis & $\begin{array}{l}\text { Round-shaped dark brownish lesions with a concentric appearance and } \\
\text { slightly sunken texture surrounded by a chlorotic halo }\end{array}$ & & D30 \\
\hline \multirow[t]{3}{*}{ P. nepalensis } & $\begin{array}{l}\text { Small spots of purplish or purple color circular in shape with a whitish } \\
\text { center of smooth texture }\end{array}$ & & P4 \\
\hline & & & P5 \\
\hline & $\begin{array}{l}\text { Semicircular lesions with the appearance of concentric rings light brown } \\
\text { in the center slightly sunken and surrounded by a purplish color growing } \\
\text { rapidly on the leaf tissue }\end{array}$ & & P7 \\
\hline \multirow[t]{2}{*}{ T. alata } & $\begin{array}{l}\text { Necrotic lesions of irregular shape rough in texture and black or sometimes } \\
\text { dark brown eventually surrounded by a chlorotic halo }\end{array}$ & & $\mathrm{T7}$ \\
\hline & $\begin{array}{l}\text { Spots initially yellow in color and semicircular or irregular in shape which } \\
\text { grows until they coalesce and make the tissue appear chlorotic. Advanced } \\
\text { lesions darken to brown with a defined center }\end{array}$ & & $\mathrm{T} 10$ \\
\hline
\end{tabular}


Septate hyphae, smooth-walled and brown; pycnidia of a subglobose to pyriform shape, glabrous, brown in color, with a size between $72-153 \mu \mathrm{m}$ in diameter. Conidia had ovoid shape between $(3.0-5.6 \mu \mathrm{m}$ long $\times 1.3-2.5 \mu \mathrm{m}$ wide), alone or confluent. Colonies presented cottony texture, irregular growth, and slightly wavy margins, with a slight orange pigmentation after 15 days of culturing (Additional file 1: Fig. 3). Molecular identification was performed according to the sequence analysis of the ITS and TEF $1 \alpha$ regions. BLASTn analysis of ITS showed identity with genera, Didymella (98\%), Epicoccum (99\%), and Phoma (98\%); while, for TEF1 $\alpha$; matched Phoma with $(88 \%)$ identity. The R15_ANT isolate was associated with the E. draconis sequence (bootstrap=97\%) (Additional file 1: Fig. 4).

Isolate R19 - Didymella rumicicola (Boerema y Loeraker) Qian Chen and L. Cai. Synonymous: Phoma rumicicola (Boerema y Loerakker) Qian Chen \& L. Cai (Chen et al. 2015).

Ellipsoidal and/or cylindrical conidia, hyaline, without septa, with dimensions between $(3.6-5.8) \times(1.4-3.0) \mu \mathrm{m}$ long $\times$ width. Pycnidia are subglobose, glabrous, brownish in color, and 75-196 $\mu \mathrm{m}$ of diameter. Colonies presented an irregular growth, cottony to granular texture, flat relief, green color, and wavy margin (Additional file 1: Fig. 5). The phylogenetic tree was constructed with sequences of the ITS and TEF1 $\alpha$ regions. The BLASTn analysis suggested the species $D$. rumicicola with (99.5\%) identity, whose sequence was the only representative for the species available in GenBank. Isolate named R19_ ANT was grouped with $D$. rumicicola sequence (bootstrap $=95 \%)$ (Additional file 1: Fig. 6).

\section{Isolate D30-Bipolaris sp.}

Brown septate hyphae, conidiophores 4.2-5.6 $\mu \mathrm{m}$ wide, septate, branched, dark brown. Conidia of (41.4$55.3) \times(13-15.9) \mu \mathrm{m}$ long $\times$ width; ellipsoidal to fusiform, 5-9 partitions. Colonies with a plush texture, irregular in shape, with the presence of concentric rings, curly margin, and green to greenish-gray color on the upper side. It has black exudates in the growth center and a slight brown pigmentation (Additional file 1: Fig. 7). Sequences were obtained only for the ITS region. Homology search analysis using BLASTn algorithm suggested the species B. zeae, B. cynodontis, and B. sorokiniana, each with (99.34\%) identity. The phylogenetic clade formed did not reliably support the separation of these species, since the bootstrap values were below (50\%). Likewise, during the morphological studies, considerable similarities were found with at least 5 other species in the genus Bipolaris described by Manamgoda et al. (2014), such as B. cynodontis, B. sorokiniana, B. coffeana, B. mediocris, and $B$. variabilis. Therefore, identification was only achieved at the genus level (Additional file 1: Fig. 8).

\section{Isolate P4 - Bipolaris zeicola (GL Stout) Shoemaker.} Synonymous: Cochliobolus carbonum RR Nelson (Manamgoda et al. 2014).

Septate hyphae, dark brown; conidiophores straight to flexible, septate, (5.1-5.9 $\mu \mathrm{m}$ wide). Conidia are ellipsoidal or cylindrical, with generally rounded ends, with sizes between (37.4-45.0) long $\times(11.2-14.8) \mu \mathrm{m}$ wide and between 4-7 conidial septa. Colonies with plush texture, irregular growth, dark gray, flat relief, and curly margin. At 15 days after culturing, it presented raised, irregular, and cottony mycelium (Additional file 1: Fig. 9). Molecular identification was performed by sequence analysis of the ITS and TEF1 $\alpha$ regions. Analysis with BLASTn algorithm suggested the species B. zeicola with (100\%) identity and B. victoriae with (98\%), which appeared to be closely related species. The P4 isolate is grouped in the clade of $B$. zeicola in the phylogenetic tree (bootstrap $=87 \%$ ) (Additional file 1: Fig. 10).

Isolate P5 - Phialemoniopsis curvata (W. Gams y W.B. Cooke) Perdomo, García, Gené, Cano \& Guarro. Synonymous: Phialemonium curvatum (Perdomo et al. 2013)

Rough hyphae often spiraling. Phialide slightly sharp in the tip without basal septum. Cylindrical to ellipsoid conidia, hyaline, unicellular, (1.9-3.5) length $\times(0.8-1.3)$ $\mu \mathrm{m}$ width often grouped in slimy heads. Cottony colonies with complete margin and flat topography showing a dark light beige halo around, this halo is sometimes grayish (Additional file 1: Fig. 11). Molecular identification was performed by sequence analysis of the regions ITS and TEF1 $\alpha$. Search analysis using the BLASTn algorithm for ITS sequences suggested three related species in the genus, Phialemoniopsis (=Phialemonium) with identity percentages above $98.8 \%$, Sarocladium strictum, and Acremonium sp., each one with an identity of (95\%). For TEF $1 \alpha$ region, only $P$. curvata with (98\%) of sequence identity was identified. Isolate P5_ANT grouped together with sequences of $P$. curvata in the same clade of the phylogenetic tree (bootstrap $=97 \%$ ) (Additional file 1: Fig. 12).

\section{Isolate P7-Stemphylium beticola Woudenb \& Hanse}

Septate hyphae of brown color and smooth wall. Solitary conidiophores, swollen at the apex conidiogenous cell. Cylindrical to ellipsoid conidia, with 1-4 transverse and 1-2 longitudinal septa of (16.3-32.9) length $\times(11.5-$ 16.3) $\mu \mathrm{m}$ width. Globose pseudotecio of (98-120 $\mu \mathrm{m}$ height and 77-116 $\mu \mathrm{m}$ in diameter). Cottony colonies growing in concentric shape with lobar margin elevated 
pulvinate mycelia of white and/or beige color according to growth and orange pigmentation (Additional file 1: Fig. 13). Molecular identification was performed using ITS sequences. BLASTn analysis suggested the genus, Stemphylium with identity percentages above 98\%, with S. beticola, S. drummondii, and S. triglochinicola as more closely related species. Isolate P7_ANT grouped together with sequences of $S$. beticola in the same clade in the phylogenetic tree (bootstrap $=90 \%$ ) (Additional file 1: Fig. 14).

\section{Isolate T7 - Alternaria thunbergiae EG Simmons \& Alcorn.}

Septate hyphae, ellipsoidal conidia, brown in color, with a size between $(60.6-67.6) \times(14.01-19.8) \mu \mathrm{m}$ long by width; between 8 and 10 transverse partitions and between 1 and 4 longitudinal partitions. Colonies with a cottony texture and pale pink color, defined borders, convex relief, and slightly wavy margin. At 15 days of growth, it presented raised relief, gray in the center, and beige at the edges (Additional file 1: Fig. 15). For molecular identification, the concatenated sequences of ITS and TEF1 $\alpha$ were used. BLASTn analysis for ITS showed homology with the species, $A$. cucumerina (98.7\%) and $A$. thunbergiae $(99.6 \%)$, and for TEF $1 \alpha$ A. thunbergiae $(98.1 \%)$ and A. cassia (96.9\%). The phylogenetic tree constructed with concatenated sequences of isolate T7_ANT showed clustering in the same clade with sequences of $A$. thunbergiae (bootstrap $=86 \%)$ (Additional file 1: Fig. 16).

Isolate T10 - Nigrospora sphaerica (Sacc.) EW Mason. Synonymous: Trichosporum sphaericum. (Mason 1927).

Septate hyphae, hyaline, or light brown; unicellular conidia, black, spherical or subspherical, smooth-walled with a size between 13.2 and $16.6 \mu \mathrm{m}$ in diameter. Fastgrowing colony, white cottony texture with a floppy appearance, entire margin, and raised relief. The coloration darkened to dark gray (Additional file 1: Fig. 17). For molecular identification, the ITS, $\beta$ Tub2, and TEF1 $\alpha$ sequences were used. BLASTn analysis for ITS suggested only the species, N. sphaerica with $100 \%$ identity; for $\beta$ Tub2, the genus Nigrospora showed between (86-100\%) of identity, and for TEF1 $\alpha N$. sphaerica and $N$. oryzae exhibited $(85.2 \%)$ of identity each. Isolate T10_ANT grouped in the same clade with sequences of $N$. sphaerica in the phylogenetic tree (bootstrap of 90\%) (Additional file 1: Fig. 18).

\section{Pathogenicity tests on detached leaves}

Incubation periods and disease incidence of each pathogen on the original host varied depending on the inoculation method used (Table 2). For $R$. crispus, the incubation period of pathogens ranged between 3.2 to 6.2 dai. $D$. rumicicola presented the highest incidence $(91.7 \%)$ in the shortest time, Bipolaris sp., induced the appearance of symptoms in D. horizontalis grass in 4.3 dai, with an incidence of (91.7\%). P. nepalensis induced symptoms between 3.1 and 6.2 dai. S. beticola showed an incidence of (100\%), by inoculation with mycelia discs. On T. alata, symptoms of the disease caused by $A$. thunbergiae were visible at 2.8 dai and symptoms caused by $N$. sphaerica at 6.5 dai, with incidences higher than (58\%).

The severity of pathogens on their respective hosts was evaluated, using AUDPC values. For the most plantpathogen combinations, rapid lesion development was favored when agar disc inoculation was used compared to foliar spray with spore-mycelium suspensions. Pathogens that showed greater disease progress on their host corresponded to D. rumicicola on $R$. crispus, Bipolaris sp., on D. horizontalis, S. beticola on P. nepalensis, and $A$. thunbergiae on T. alata. In the control treatments, there were no visible symptoms (Fig. 1). Symptoms exhibited in inoculated detached leaves were presented in Fig. 2. D. rumicicola (R19), Bipolaris sp., (D30), S. beticola (P7), and $A$. thunbergiae (T7) were selected for the pathogenicity tests on whole seedlings, because those developed greater infection areas and/or in a shorter incubation period on their respective hosts.

\section{Pathogenicity tests on seedlings}

The four selected pathogens showed symptoms on seedlings of their original hosts between 1 to 4 dai, with an incidence of $(100 \%)$ for each case, while the control treatments remained healthy. Symptoms exhibited by $D$. rumicicola on $R$. crispus appeared on average from 4 dai, which consisted of small reddish or purplish circular spots, often surrounded by chlorotic and necrotic areas in advanced stages, affecting (8.35\%) of the leaf area at 8 dai (Fig. 3A, B). Lesions of Bipolaris sp. on D. horizontalis appeared on average at 1.7 dai, showing dark brown spots initially with a whitish center, which grew elongated with a slight burning or tan appearance, causing the greatest severity detected in the foliar area of the plants (38.31\%) in a period of 5 dai (Fig. 3C, D). S. beticola showed symptoms on $P$. nepalensis from 2.5 dai, with initially white lesions, round, and slightly depressed texture, which grew to become oval, concentric, and dark brown, with (21.6\%) of foliar area affected at 5 dai (Fig. 3E, F). Symptoms of $A$. thunbergiae on T. alata appeared earlier, with a mean of 1 dai, showing dark gray and/or dark brown spots, irregular in shape and rigid texture, which rapidly advanced until they coalesced causing large necrotic areas. This pathogen affected (28.6\%) of the leaf area in only 3 dai (Fig. 3G, H). 


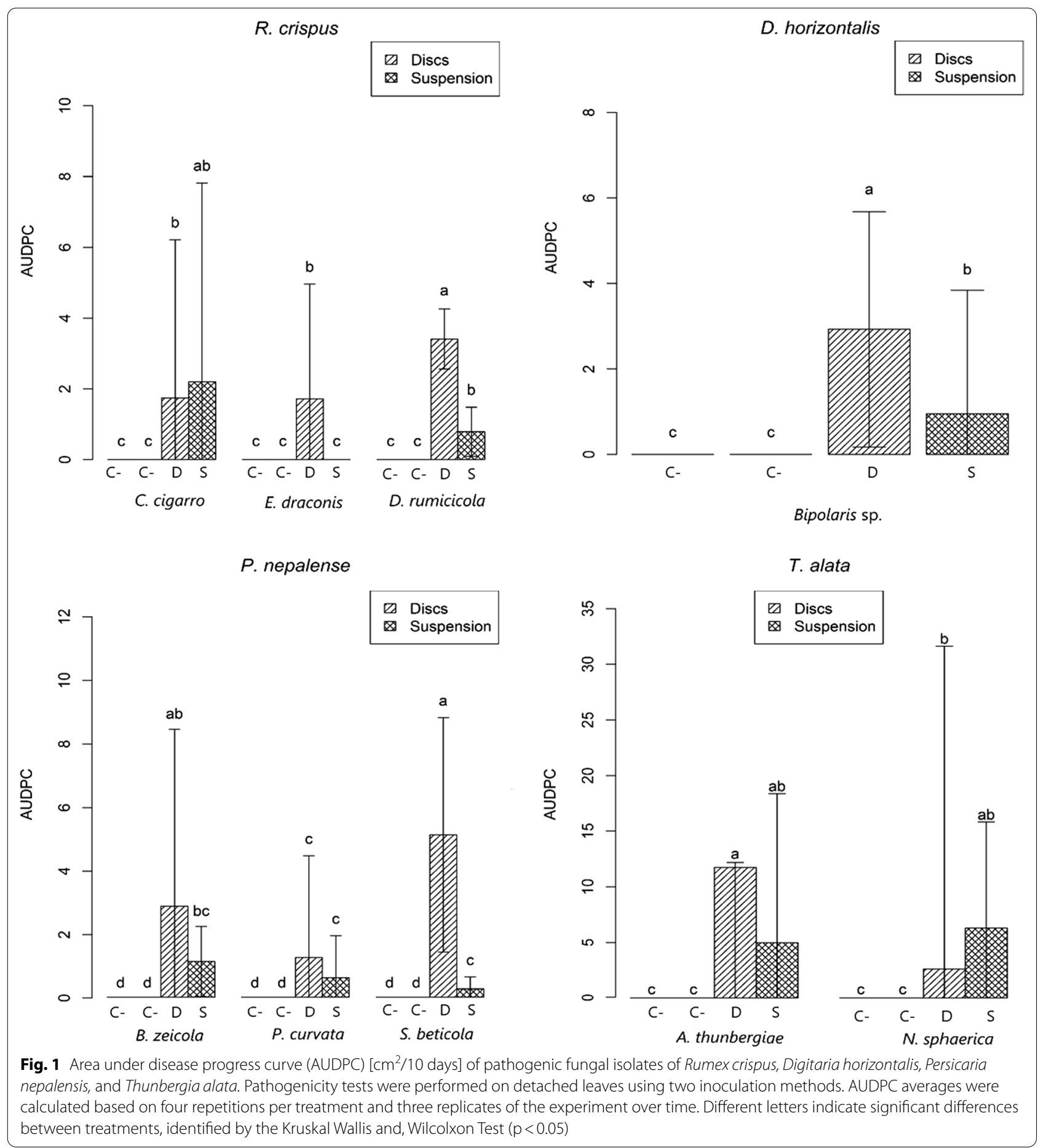

\section{Discussion}

In the present investigation, eight of nine phytopathogenic fungi detected were identified at the species level and one at the genus level. From the weed, $R$. crispus, 3 fungal species having the ability to infect and to cause disease were isolated and identified (C. cigarro, E. draconis, and D. rumicicola). No reports of these fungal agents affecting this species were found after a comprehensive review of the available literature, so to the best of our knowledge, this is the first record worldwide. Found reports referred to pathogens such as Alternaria alternata causing irregular dark brown foliar lesions, with 


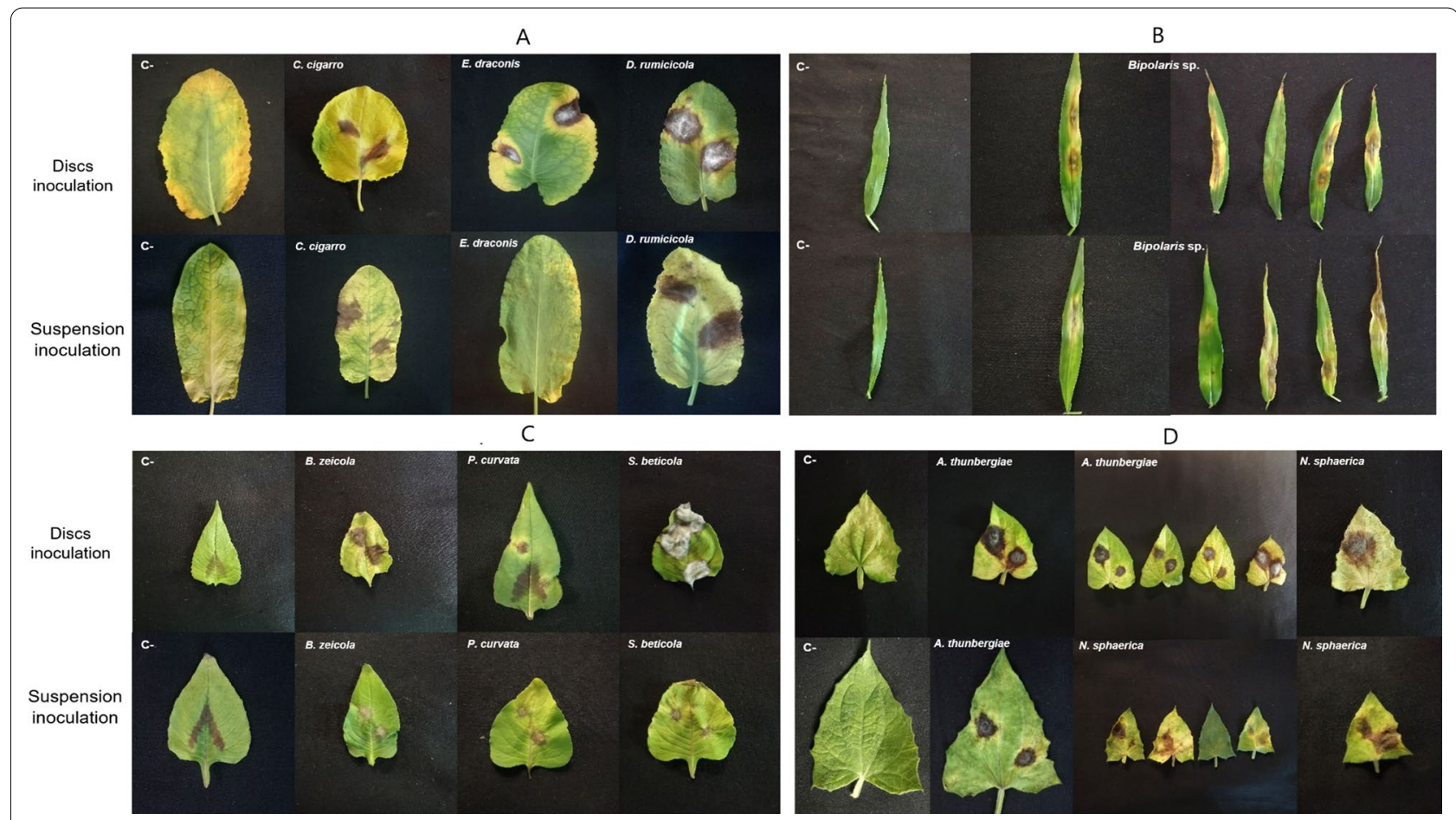

Fig. 2 Symptoms in detached leaves of weed hosts caused by fungal isolates tested, using two inoculation methodologies: mycelial discs and suspension of spores-mycelia fragments and their respective negative controls (C-). A Rumex crispus. B Digitaria horizontalis. C Persicaria nepalensis. D Thunbergia alata. Each figure is representative of its respective treatment. Each treatment consisted of four repetitions and three replications

the presence of concentric rings in Uruguay (Kaspary et al. 2019); the powdery mildew, Erysiphe quercicola S. Takam. \& U. Braun., causing incidences up to $100 \%$ and severities between $40-80 \%$ in Brazil (Dorneles et al. 2019); and Uromyces rumicis (Schumach.) G. Winter, in Europe (Hatcher et al. 2009). Phoma rumicicola Boerema

Table 2 Incubation period and disease incidence percentage of the pathogens isolated on Rumex crispus, Digitaria horizontalis, Persicaria nepalensis and Thunbergia alata

\begin{tabular}{|c|c|c|c|c|c|c|c|c|c|}
\hline \multirow[t]{2}{*}{ Weeds } & \multirow[t]{2}{*}{ Pathogenic fungi } & \multicolumn{4}{|c|}{ Incubation period (days) } & \multicolumn{4}{|c|}{ Incidence (\%) } \\
\hline & & Agar disc & $\mathrm{KW}^{1}$ & $\begin{array}{l}\text { Inoculum } \\
\text { suspension }\end{array}$ & $\mathrm{KW}^{1}$ & Agar disc & $K W^{2}$ & $\begin{array}{l}\text { Inoculum } \\
\text { suspension }\end{array}$ & $\mathrm{KW}^{1}$ \\
\hline \multirow[t]{4}{*}{ R. crispus } & C. cigarro & 5.8 & a & 5.3 & a & 33.3 & c & 41.7 & c \\
\hline & E. draconis & 4.3 & $a b$ & $N D^{2}$ & c & 66.7 & $b$ & 0.0 & $d$ \\
\hline & D. rumicicola & 3.2 & $b$ & 6.2 & a & 91.7 & a & 75.0 & $a b$ \\
\hline & Control & $N D^{2}$ & c & $N D^{2}$ & c & $N D^{2}$ & $d$ & $N D^{2}$ & $d$ \\
\hline \multirow[t]{2}{*}{ D. horizontalis } & Bipolaris sp. & 4.3 & $b$ & 7.5 & a & 91.7 & a & 41.7 & $b$ \\
\hline & Control & $N D^{2}$ & $c$ & $N D^{2}$ & c & $N D^{2}$ & c & $N D^{2}$ & c \\
\hline \multirow[t]{4}{*}{ P. nepalensis } & B. zeicola & 3.9 & $a b$ & 6.2 & a & 75.0 & $a b$ & 75.0 & $a b$ \\
\hline & P. curvata & 4.5 & $a b$ & 5.3 & $a b$ & 41.0 & $c$ & 33.0 & $c$ \\
\hline & S. beticola & 3.1 & $b$ & 5.7 & a & 100.0 & a & 50.0 & $b c$ \\
\hline & Control & $\mathrm{ND}^{2}$ & c & $\mathrm{ND}^{2}$ & c & $\mathrm{ND}^{2}$ & $d$ & $\mathrm{ND}^{2}$ & $d$ \\
\hline \multirow[t]{3}{*}{ T. alata } & A. thunbergiae & 2.8 & $\mathrm{~b}$ & 3.3 & ba & 91.7 & a & 66.7 & $a b$ \\
\hline & N. sphaerica & 6.5 & a & 6.1 & $\mathrm{a}$ & 58.3 & $b$ & 66.7 & $a b$ \\
\hline & Control & $N D^{2}$ & c & $N D^{2}$ & c & $N D^{2}$ & c & $N D^{2}$ & c \\
\hline
\end{tabular}

Values with the same letter do not differ statistically $(p<0.05)$

${ }^{1}$ Kruskal-Wallis and Wilcoxon test

${ }^{2} \mathrm{ND}$, Not determined 
\& Loer (=Didymella rumicicola) was firstly reported on R. obtusifolius in New Zealand (Boerema et al. 1980), whose symptoms in the field consisted of red or violaceous spots, about $10 \mathrm{~mm}$ in diameter and with slightly sunken and dark centers, similar to those caused by $D$. rumicicola (R19) on $R$. crispus in this study.

In the case of the weed, $D$. horizontalis, only one pathogenic isolate was obtained belonging to the genus Bipolaris sp. The available literature reported it as a genus commonly associated with pathogens of various plants of the Poaceae family, both cultivated and noncultivated/wild, although they can also behave as endophytes and saprophytes (Marin et al. 2017). De Lima et al. (2012), reported Bipolaris sp., affecting several species of the Digitaria complex and other grasses such as: Sorghum halepense L., and Chloris gayana Kunth, causing leaf spots and blights in the field. However, the disease severity of isolates was not evaluated, nor were the botanical and fungal specimens accurately identified. Tilley (2002) concluded that the biocontrol potential of Curvularia intermedia for $D$. sanguinalis was limited in cereal crops because it affected crop species such as: sorghum, rice, and corn. However, it can be successfully applied to control grasses of susceptible Digitaria spp., present in cotton, soybean, and peanut crops. Flores et al. (2018) indicated as a potential biological control agent of $D$. horizontalis seeds, isolates classified in the genera, Alternaria sp., Curvularia sp., and Fusarium sp., with incidences of 13.4, 13.4, and 6.7\%, respectively. This fact is of particular importance because it leads us to think about the usefulness of possible mycoherbicides with pre-emergent action by reducing and/or inhibiting seed germination.

In the literature, no investigations were identified on the pathogenicity of fungi with potential for biocontrol of the weed, $P$. nepalensis. In the present study, 3 fungal agents with infective and pathogenic capacity on this weed were isolated and identified (B. zeicola, P. curvatum, and S. beticola). In China and India, countries where it is believed to be the origin of this plant, there were reports of the fungi, Microbotryum polygoni-alati (Thirum. \& Pavgi) Vánky and M. nepalensis associated with this weed, but their pathogenicity was not tested (Denchev and Denchev 2017).

Two species of fungi were isolated from $T$. alata (A. thunbergiae and N. sphaerica). A. thunbergiae has been reported to affect $T$. alata in various places of the world, but not in Colombia, why it constituted the first report for this country. The first report occurred in $T$. alata plants in Florida, USA (Leahy 1992), later in Brazil (Melo et al. 2009), and recently in Europa (Newbery et al. 2019). In these last two cases, inoculations of adult and young plants, respectively, under greenhouse conditions, resulted in an incubation period of 12 days when artificial wounds were made on leaves and 15 days when no artificial wounds were caused. In the present study, when inoculating young plants symptoms appeared on average 1dai in controlled climatic chamber conditions affecting $(28 \%)$ of the leaf area in just 3 dai. On the other hand, it is worth highlighting the urgent need for control strategies for this plant, due to its highly invasive nature on native forests and ecosystems in Colombia. N. sphaerica was also identified as a pathogen on T. alata plants. $N$. sphaerica showed similar effects to those observed for $A$. thunbergiae, in the first pathogenicity tests. N. sphaerica has also been identified as a potential biological control agent of Rottboellia cochinchinensis (Lour.), an important weed in rice crops and Wisteria sinensis (Sims), a common arboreal vine, on which it causes necrotic lesions that initially consist of grayish spots of irregular shape often surrounded by a yellow zone (Soylu et al. 2011). These associations lead the authors to think about the possible expansion of biological targets to be controlled with the same microorganism or a mixture of these. In addition, the risk of affecting non-target hosts should be carefully evaluated as discussed below.

In the first stage of pathogenicity tests, it was shown that both methodologies were effective in inducing the pathogen infection capacity. However, in most situations, the inoculation with agar discs with mycelium, caused better results compared to the inoculation of a suspension of spores and/or mycelial fragments. With the second method, possibly the suspension concentration used was insufficient to generate disease, or this pathogen needs the microenvironment generated by agar-mycelium discs, as evidenced with $E$. draconis, which did not present symptoms in plants when inoculating with spore-mycelial suspension but showed symptoms when inoculated with mycelial discs. Eventually, it could be considered a weak or secondary pathogen of $R$. crispus. Similar results have also been reported in other investigations regarding the use of both methodologies highlighting greater effectiveness with inoculation using discs, especially for those fungi that do not sporulate in an artificial medium (Cardona and Castaño 2019). In the second pathogenicity test, although selected fungal isolates demonstrated infective capacity on their respective host seedlings, infection times and disease development depended on the type of host-agent interaction tested. In this sense, additional tests are required including other factors such as inoculum concentration and plant development stage, to reduce infection times and increase disease development rates. According to Barreto and Evans (1998), there is a need to apply fungi as bio-herbicides in the initial stages of growth, to lead to a more effective biocontrol before flowering and reproduction occur. 


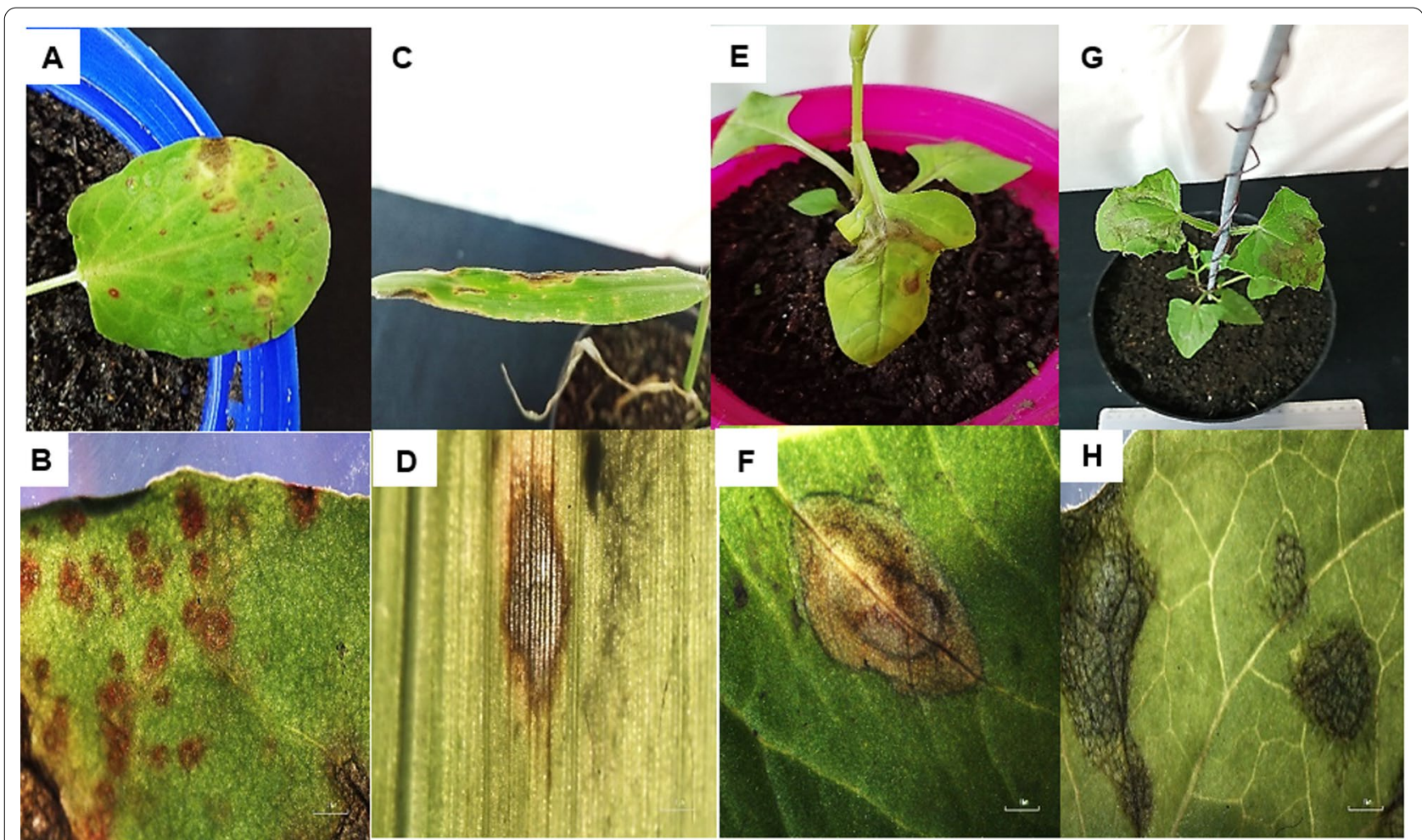

Fig. 3 Symptomatology exhibited after inoculation of the pathogens on their respective host seedlings. A, B Didymella rumicicola on Rumex crispus at 8 dai. C, D Bipolaris sp., on Digitaria horizontalis at 5 dai. E, F. Stemphylium beticola on Persicaria nepalensis at 5 dai. G, $\mathbf{H}$ Alternaria thunbergiae on Thunbergia alata at 3 dai

Thus, this research confirmed the ability of $D$. rumicicola, Bipolaris sp., S. beticola, and A. thunbergiae to successfully establish on their respective hosts at an early stage of plant development (4-8 true leaves). On the other hand, it could also be thought that the application of pathogens in stages of 2 to 4 leaves was even more effective than that obtained in the present results, in a similar way to what happens with the application of chemical herbicides.

\section{Epidemiological risk}

Considering avocado, tomato, blackberry, and bean crops, as the representative in the region sampled, it is convenient to investigate possible epidemiological risks associated with the isolated weed pathogens. In avocado crops in Mexico, a fungal isolate identified as $C$. cigarro was reported to cause anthracnose in fruits (Fuentes et al. 2020), and in Colombia C. kahawae subsp. cigarro $(=C$. cigarro) was found affecting blackberry (Afanador et al. 2014), and tree tomato (Rojas et al. 2018). According to the literature review, in table tomato and bean crops, there were no known pathogenic interactions associated with the fungi identified in the present research. However, it is worth highlighting the pathogenicity of $B$. zeicola on cultivated plants of the Poaceae family such as: corn, oats, wheat, and sorghum (Marin et al. 2017). Although these associations could warn about possible risks in crops, it is important to take into consideration other types of factors such as the specificity of the pathogenic strains (special forms and/or races) and the plant genotypes, among others. For example, three special forms of C. gloeosporioides have been registered and commercialized as bio-herbicides and at least 16 other species have been evaluated as candidates (Zhang et al. 2003). Phoma macrostoma (=Didymella macrostoma), has been registered and commercialized in the US and Canada for the control of dicot weeds (Taraxacum officinale, Senecio vulgaris, Cirsium arvenses, and Cicer arietinum) without reports of affecting monocotyledonous plants (Hubbard et al. 2016). The commercial product SMOLDER (Alternaria destruens EG Simmons) has been formulated for the control of Cuscuta spp., and CASST, (Alternaria cassiae Jurair and A. Khan) to control Cassia spp. plants in soybean and peanut crops in the USA (Dagno et al. 2012). In this respect, under the mycoherbicide approach, the use of pathogens for biocontrolling lies in limiting the range of use and detecting in which type of crop it can be used and in which not, 
understanding the biology of the product and the restrictions associated with its application (Bailey 2014). Similarly, extensive studies should be performed on native flora to avoid damage in natural ecosystems. Here, few isolates from weed hosts were reported as potential bio-herbicides. However, it is important to explore the genetic diversity of pathogen populations with more comprehensive sampling because they may contain more aggressive or highly host-specific isolates that may be valuable to reach the biocontrol goals more efficiently and maybe with less potential impact in non-target organisms. In any situation, it is evident that it is necessary to study the range of host-pathogen relationships and better predict the risk of impacts on non-target plants, to obtain the desired environmental, economic, and agronomic benefits.

\section{Conclusions}

This research made it possible to contribute to the finding and precise identification of nine fungal strains with pathogenic capacity on 4 ecologically and economically important weeds in moderate cold climate crops in Antioquia, Colombia. Some isolates were new reports of fungal pathogens for these weeds worldwide highlighting the importance of such local studies. Results shown here represent the first stage of bio-prospecting for alternative weed management with a mycoherbicidal approach. Of course, there is a large gap between experimental detection and the use of such agents in a practical and even commercial way due to the various feasibility and support studies that are required to resolve questions generated so far. However, the detection of such pathogenic interactions for the first time and the identification of potential control agents, increase the prospects for their research and allows to open new pathways to give continuity to the development of biological control programs for weeds in Colombia.

\section{Abbreviations \\ ANOVA: Analysis of variance; BLASTn: Basic local alignment search tool; B- TUB2: Tubulin beta chain; DAl: Days after inoculation; ITS: Internal transcribed spacer region; NCBI: National Centre for Biotechnology and Information; PDA: Potato dextrose agar; TEF1-a: Translation elongation factor 1-a.}

\section{Supplementary Information}

The online version contains supplementary material available at https://doi. org/10.1186/s41938-021-00467-6.

Additional file 1. Supplementary information.

\section{Acknowledgements}

We thank people from Fitotecnia Tropical laboratory and research group and Politécnico Colombiano Jaime Isaza Cadavid and Universidad Nacional de Colombia branch Medellín.

\section{Authors' contributions}

All authors contributed equally to the work presented in this paper. The authors read and approved the final manuscript. YM (Corresponding author): Execution of experiments, design of work, analysis, and interpretation of results. DC: Review, analysis, and interpretation of results. JM: Review, analysis, and interpretation of results. LP: Review, analysis, and interpretation of results. All authors read and approved the final manuscript.

\section{Funding}

The authors thank the Fitotecnia Tropical research group, for their financial support to carry out this research work.

\section{Availability of data and materials}

The data that support the findings of this study are available from the corresponding author, Yerly Mira, upon reasonable request.

\section{Declarations}

Ethics approval and consent to participate

Not applicable.

\section{Consent for publication}

Not applicable.

\section{Competing interests}

The authors declare that they have no competing interests.

\section{Author details}

${ }^{1}$ Departamento de Ciencias Agronómicas, Facultad de Ciencias Agrarias, Universidad Nacional de Colombia, Sede Medellín, Cra 65 No 59A-110, Núcleo El Volador, B11, Medellín, Antioquia, Colombia. ${ }^{2}$ Facultad de Ciencias Agrarias, Politécnico Colombiano Jaime Isaza Cadavid, Cra 48 \# 7-151, P19-115, Medellín, Antioquia, Colombia.

Received: 23 June 2021 Accepted: 29 August 2021

Published online: 09 September 2021

\section{References}

Afanador L, González A, Gañán L, Mejía J, Cardona N, Álvarez E (2014) Characterization of the colletotrichum species causing anthracnose in Andean Blackberry in Colombia. Plant Dis 98:1503-1513. https://doi. org/10.1094/PDIS-07-13-0752-RE

Auld BA, Hetherington SD, Smith HE (2003) Advances in bio-herbicide formulation. Weed Biol Manag 67:61-67. https://doi.org/10.1046/j. 1445-6664.2003.00086.x

Bailey K (2014) The bio-herbicide approach to weed control using plant pathogens. In: Abrol D (ed) Integrated pest management current concepts and ecological perspective. Elsevier

Barnett H, Hunter B (2006) Illustrated genera of imperfect fungi, 4th edn. The American Phytopatological Society

Barreto R, Evans H (1998) Fungal pathogens of Euphorbia heterophylla and E. hirta in Brazil and their potential as weed biocontrol agents. Mycopat 141:21-36. https://doi.org/10.1023/A:1006899831867

Boerema GH, Loerakker WM, Laundon GF (1980) Phoma rumicicola sp. nov. a cause of leaf spots on Rumex obtusifolius. NZ J Bot 18(4):473-476. https://doi.org/10.1080/0028825x.1980.10425168

Cabral A, Azinheira HG, Talhinhas P, Batista D, Ramos AP, Silva MD, Oliveira H, Várzea V (2020) Pathological morphological cytogenomic biochemical and molecular data support the distinction between Colletotrichum cigarro comb. Et stat. nov. and Colletotrichum kahawae. Plants 9(4):1-22. https://doi.org/10.3390/plants9040502

Cai X, Gu M (2016) Bio-herbicides in organic horticulture. Horticulturae 2(2):3-8. https://doi.org/10.3390/horticulturae2020003

Campbell C, Madden L (1990) Introduction to plant disease epidemiology. Wiley, New York, p 532

Carbone I, Kohn L (1999) A method for designing primer sets for speciation studies in filamentous ascomycetes. Mycol 91(3):553-556. https://doi. org/10.1080/00275514.1999.12061051 
Cárdenas B, Baptiste M, Castaño N (2017) Plantas exóticas con alto potencial de invasión en Colombia. Instituto de Investigación de Recursos Biológicos Alexander Von Humboldt

Cardona L, Castaño J (2019) Comparación de métodos de inoculación de Fusarium oxysporum f. sp. lycopersici (Sacc.) Snyder and Hansen causante del marchitamiento vascular del tomate. Revista Acad Colomb Ci Exact 43:167-227. https://doi.org/10.18257/raccefyn.854

Castaño J (2012) Guía ilustrada de hongos promisorias para el control de malezas insectos nemátodos y hongos fitopatógenos. Universidad de Caldas Manizales Colombia

Chen Q, Jiang J, Zhang G, Cai L, Crous P (2015) Resolving the phoma enigma. Stud Mycol 82:137-217. https://doi.org/10.1016/j.simyco.2015. 10.003

Dagno K, Lahlali R, Diourté M, Jijakli MH (2012) Present status of the development of mycoherbicides against water hyacinth: successes and challenges: a review. Biotechnol Agron Soc Environ 16(3):360-368

Denchev TT, Denchev CM (2017) Contributions to the smut fungi of Africa: first record of microbotryum polygoni-alati. Mycobiota 7:19-24 https://doi.org/10.12664/mycobiota.2017.07.04

Dias N, Christoffoleti PJ, Tornisielo VL (2005) Identificação taxonômica de espécies de capim-colchão infestantes da cultura da cana-de-açúcar no estado de São Paulo e eficácia de herbicidas no controle de Digitaria nuda. Bragant 64(3):389-396. https://doi.org/10.1590/s000687052005000300008

Dorneles KR, Lamego FP, Caratti FC, Victoria AD, Pazdiora PC, Dalla KL (2019) First report of powdery mildew caused by Erysiphe quercicola on curly dock (Rumex crispus) in Brazil. Plant Dis 103:3-11. https://doi.org/10. 1094/PDIS-09-18-1565-PDN

Doyle JJ, Doyle JL (1990) Isolation of plant DNA from fresh tissue. Focus 12:13-15

De Lima K, DeAlmeida B, Viera H (2012) Fungos associados a plantas invasoras na cultura de café em experimento tipo face (Free Air CO2 Enrichmente). In: Embrapa Meio Ambiente (ed) EMBRAPA

Flores E, Rocha P, Rodrigues G (2018) Seeds of weeds as an alternative host of phytopathogens. Arq Inst Biol 85:1-7. https://doi.org/10.1590/18081657000972017

Fried G, Chauvel B, Reynaud P, Sache I (2017) Decreases in crop production by non-native weeds pests and pathogens. In: Vilà E, Hulme I (eds) Impact of biological invasions on ecosystem services. Invading natureSpringer series in invasion ecology. Springer, Cham

Fuentes D, Silva H, Guarnaccia V, Mora J, Aranda S, Bautista N, Téliz D (2020) Colletotrichum species causing anthracnose on avocado fruit in Mexico: current status. Plant Pathol 69:1513-1528. https://doi.org/10. 1111/ppa.13234

Groenewald JZ, Nakashima C, Nishikawa J, Shin HD, Park JH, Jama AN, Groenewald M, Braun U, Crous P (2013) Species concepts in Cercospora: spotting the weeds among the roses. Stud Mycol 75:115-170. https:// doi.org/10.3114/sim0012

Hall T (1999) BioEdit: a user-friendly biological sequence alignment editor and analysis program for Windows 95/98/NT (Ser. 41:95-98.) Nucl Acids Symp

Hatcher PE, Brandsaeter LO, Davies G, Lüscher A, Hinz HL, Eschen R, Schaffner U (2009) Biological control of Rumex species in Europe: opportunities and constraints. In: Proceedings of the XII international symposium on biological control of weeds La Grande Motte France 22-27 April 2007 470-475. https://doi.org/10.1079/9781845935061.0470

Heap I (2014) International survey of herbicide resistant weeds. Herbicide Resistance Action Committee the North American and the Weed Science Society of America. https://www.weedscience.org

Holdridge LR (1982) Ecología basada en zonas de vida. J Chem Inf Model. https://doi.org/10.1017/CBO9781107415324.004

Hubbard M, Taylor W, Bailey K, Hynes R (2016) The dominant modes of action of macrocidins bio-herbicidal metabolites of Phoma macrostoma differ between susceptible plant species. Environ Exp Bot 132:80-91. https://doi.org/10.1016/j.envexpbot.2016.08.009

Kaspary TE, García MA, Stewart S, Casaroto G, Ramos R, Bellé C (2019) First report of Alternaria alternata causing leaf spot on Rumex crispus in Uruguay. Plant Des 103:21-39. https://doi.org/10.1094/ PDIS-03-19-0590-PDN
Kumar S, Stecher G, Li M, Knyaz C, Tamura K (2018a) MEGA X: molecular evolutionary genetics analysis across computing platforms. Mol Biol Evol. https://doi.org/10.1093/molbev/msz312

Kumar V, Aggarwal AN, Njali K (2018b) Bio-herbicidal concept: a novel strategy to control weeds. In: Singh J, Sharma D, Kumar G (eds) Microbial bioprospecting for sustainable development. Springer

Leahy R (1992) Alternaria leaf spot of Thunbergia. Florida Dept Agric Consum Serv 1471(352):1-2

Manamgoda D, Rossman AY, Castlebury LA, Crous PW, Madrid H, Chukeatirote $E_{1}$ Hyde K (2014) The genus bipolaris. Stud Mycol 79(1):221-288. https://doi.org/10.1016/j.simyco.2014.10.002

Marin F, Senwanna C, Cheewangkoon R, Crous P (2017) New species and records of Bipolaris and Curvularia from Thailand. Mycosp 8(9):15561574. https://doi.org/10.5943/mycosphere/8/9/11

Mason S (1927) Date culture in Egypt and the Sudan. USDA bulletin No. 1457

Melo MP, Soares DJ, Araújo J, Tostes G (2009) Alternaria leaf spot caused by Alternaria thunbergiae recorded for the first time on Thunbergia alata from Brazil. Australas Plant Dis Notes 4(1):23-25. https://doi.org/10. 1071/DN09010

Mira YD (2020) Potencial fitopatogénico de hongos asociados a arvenses en cultivos del Altiplano Oriente de Antioquia Colombia. Dissertation, Universidad Nacional de Colombia. https://repositorio.unal.edu.co/ handle/unal/79327

Newbery F, Beal E, Scrace J (2019) First record of Alternaria thunbergiae on Thunbergia alata in Europe. New Dis Rep 39(1):14. https://doi.org/10. 5197/j.2044-0588.2019.039.014

Perdomo H, García D, Gené J, Cano J, Sutton D, Summerbell R, Guarro J (2013) Phialemoniopsis a new genus of Sordariomycetes and new species of Phialemonium and Lecythophora. Mycologia 105(2):398-421. https://doi.org/10.1128/JCM.01979-1

Quijano M, Sierra J, Gaviria B, Navarro R, Castaño M, Sánchez D, Marín D, Arcila K, Rojas J (2019) Historia vida y poderes de una especie invasora: estrategia para su control y manejo. Fondo Editorial Universidad Católica del Oriente, Cornare

Ramírez J (2017) Weeds in crops of avocado tree tomato pasture and forage and their relation to yield and production costs. Cult Trop 38(3):14-23

Rojas P, Pardo J, Calderón C, Vargas N, Cabrera L, Restrepo S, Jiménez P (2018) First report of colletotrichum kahawae subsp. ciggaro causing anthracnose disease on tree tomato in Cundinamarca Colombia. Plant Dis 102(10):2031-2031. https://doi.org/10.1094/PDIS-02-18-0353-PDN

Schneider C, Rasband W, Eliceiri K (2012) NIH Image to ImageJ: 25 years of image analysis. Nat Methods 9(7):671-675. https://doi.org/10.1038/ nmeth.2089

Schwarzländer M, Hinz H, Winston RL, Day M (2018) Biological control of weeds: an analysis of introductions rates of establishment and estimates of success worldwide. Biol Control 63:319-331. https://doi.org/ 10.1007/s10526-018-9890-8

Soylu S, Dervis S, Soylu E (2011) First report of Nigrospora sphaerica causing leaf spots on chinese wisteria: a new host of the pathogen. Plant Dis 95(2):219-219. https://doi.org/10.1094/PDIS-10-10-0770

The R Core Time (2019) R: a language and environment for statistical computing. R Foundation for Statistical Computing Vienna Austria. http:// www.r-project.org/index.html\%0A

Tilley AM, Walker HL (2002) Evaluation of Curvularia intermedia (Cochliobolus intermedius) as a potential microbial herbicide for large crabgrass (Digitaria sanguinalis). Biol Control 25:12-21. https://doi.org/10.1016/ S1049-9644(02)00035-X

Triolet M, Guillemin J, Andre O, Steinberg C (2019) Fungal-based bioherbicides for weed control: a myth or a reality? Weed Res 60(3):60-77. https://doi.org/10.1111/wre.12389

White T, Bruns T, Lee S, Taylor J (1990) Amplification and direct sequencing of fungal ribosomal RNA genes for phylogenetics. In: Innis MA, Gelfand DH, Sninsky JJ, White TJ (eds) PCR protocols: a guide to methods and applications. Academic Press

Zaller JG (2004) Ecology and non-chemical control of Rumex crispus and R. obtusifolius (Polygonaceae): a review. Weed Res 44(6):414-432. https:// doi.org/10.1111/j.1365-3180.2004.00416.x 
Zhang W, Wolf T, Bailey K, Mortensen K, Boyetchko S (2003) Screening of adjuvants for bio-herbicide formulations with. Biol Control 26:95-108 https://doi.org/10.1016/S1049-9644(02)00133-0

Zohaib A, Abbas T, Tabassum T (2016) Weeds cause losses in field crops through allelopathy. Not Sci Biol 8(1):47-56. https://doi.org/10.15835/ nsb.8.1.9752

\section{Publisher's Note}

Springer Nature remains neutral with regard to jurisdictional claims in published maps and institutional affiliations.
Submit your manuscript to a SpringerOpen ${ }^{\ominus}$ journal and benefit from:

- Convenient online submission

- Rigorous peer review

- Open access: articles freely available online

- High visibility within the field

- Retaining the copyright to your article

Submit your next manuscript at $\boldsymbol{\nabla}$ springeropen.com 